\title{
Factors Affecting the Internal Audit Effectiveness: A Research of the Turkish Private Sector Organizations
}

\author{
Ahmet ONAY'
}

\begin{abstract}
The aim of present study is to examine the factors that have an impact on internal audit effectiveness (IAE) in Turkey. The datas of research were obtained from 187 internal auditors who are members of The Institute of Internal Auditors-Turkey, working in private sector organizations through the questionnaire prepared as a result of the item pool assessment. The relationship between the IAE and six main factors revealed by applying Principle Component Analysis was tested with Multiple Regression Analysis. The results supported that specifications of internal audit had a direct impact on IAE. The results of study showed that the factors that have an impact on IAE are management's support, competence, independence, participation in risk management activities and cooperation with external auditor, respectively. This study has replaced one of the missing pieces of the literature. The results would underpin executives and academics to focus on IAE in Turkish private sector.
\end{abstract}

Keywords: internal audit effectiveness; internal audit in developing countries; private sector audit; principle component analysis; regression analysis.

\section{Introduction}

Corporate scandals that have shaken the world in last 30 years have increased internal audit function to a much more prominent position within the organizations than before. Due to its unique position within organizations, internal audit has become an integral component of the corporate governance mosaic today (Soh \& Martinov-Bennie, 2011, 605). Nowadays, internal audit is considered as the most prominent cornerstone of corporate governance (Gramling et al., 2004, 196). Effectiveness is one of the most prominent issues that internal auditors should consider in order to establish good governance both in terms of their functions and organizations. The prominence of internal audit's role in the field of corporate governance causes internal audit effectiveness (hereafter IAE) to remain a topic of constant interest (Endaya \& Hanefah 2016, 161).
Internal audit is a dynamic profession that needs to constantly update itself in order to respond to today's conditions of changing business environment. In addition to providing assurance services to business operations, internal audit profession has also to provide consultancy services to senior management as a strategic mind co-partner to meet its changing needs. By taking on a consultancy role, internal auditors reach the potential to bring their professions to a respectable position that adds value to their businesses. Beyond its traditional role, focusing on internal control and financial compliance, internal audit can establish good governance in organization by undertaking a broad consultancy role within the scope of risk management activities. Today's ever-changing business environment has made it more prominent to explore how effectively internal audit fulfills its objectives (Alzeban \& Gwilliam, 2014).

\footnotetext{
Author profile: Ahmet Onay is a Assistant Professor of Accounting at Eskisehir Tecnical University. He has a Ph.D. in Accounting from the Anadolu University. Onay's research interest and publications are in the areas of accounting education, enterprise risk management, International Financial Reporting Standards, and internal audit.

Conflict of interest disclosure: The authors declare that they have no conflict of interest.

${ }^{1}$ Eskisehir Tecnical University, Vocational School of Transportation, Basın Şehitleri Ave. 152, 26470 Eskisehir / Turkey, ahmet_onay@eskisehir.edu.tr
} 
As stated in current definition made by The Institute of Internal Auditors (IIA), "internal audit acts with a systematic and disciplined approach to evaluate and improve effectiveness of organization's risk management, control and governance processes" (IIARF, 2013, 2). The current definition of internal audit points to existence of a future-oriented paradigm that supports those who are audited to conduct their activities more effectively and efficiently (Goodwin, 2004). The main purpose of internal audit is to provide organizational effectiveness and efficiency by bringing constructive criticism (Cohen \& Sayag, 296, 2010). According to Chambers (1992), effectiveness means "doing the right thing"; efficiency means "doing well". Effectiveness is more prominent than efficiency. It is not prominent how efficiently service is provided if internal audit is not effective (Lenz et al., 2018, 3).

Internal audit, which is a dynamic profession whose scope and boundaries change in line with new business needs, deserves concern and attention of more future academic research (Lenz et al., 2018, 1). Many studies (Arena \& Azzone 2009; Mihret et al. 2010; Coetzee \& Erasmus, 2017) point out that studies focusing on the factors affecting the effectiveness of internal audit and their relationship with each other should be conducted. The literature needs extensive empirical studies that examine more variables that have a potential impact on IAE. The narrow literature dealing with IAE in private sector enterprises has shown that factors affecting effectiveness and possible relationships are not fully examined. There is a need to conduct further research in this specific fields.

The vast majority of researches in literature to determine the factors that have an impact on IAE are focused on public sector. When examining sector on which current studies focused, research method, sampling, and hypotheses in previous studies, it is clear that factors directing IAE need more research (Erasmus \& Coetzee, 2018, 93). Many of studies for public sector have suggested that researches should be repeated for private sector in future studies (Coetzee \& Erasmus, 2017, 238). The lack of consensus on factors affecting IAE in the previous studies for private sector indicates the gap of research area. There are not enough studies in the international literature to meet the importance of the subject, and many academics (Mihret \& Yismaw, 2007; Ahmad et al., 2009; Mustika, 2015; Endaya \& Hanefah, 2016; Salehi, 2016; Erasmus \& Coetzee, 2018) recommend further research, especially focusing on developing countries. This situation makes
IAE a field of study that should be focused in private sector businesses operating in developing countries. For these reasons listed above, it is aimed to contribute to the elimination of existing gap in the research area in this study.

\section{Literature and Hypothesis Development}

\subsection{Internal Audit Effectiveness}

The effectiveness of internal audit function plays a major role in the success of organization. In order to determine factors that have an impact on IAE, many studies have been conducted on samples consisting of participants of both parties demanding and supplying internal audit service. International Standards for theProfessional Practice of Internal Auditing (ISPPIA) has been used as a basic guide in selection of variables that should be tested in order to determine IAE. In addition, factors such as economic conditions of countries, directives of regulatory public institutions and sector in which the enterprise operates, influenced determination of variables in the models developed by researchers.

Sarens (2009) recommended that characteristics of internal auditors and internal audit functions be examined as prominent study topics for future studies on IAE as a result of the academic examination made on papers presented at the Internal Audit and Corporate Governance Conference held in Netherlands.

Arena \& Azzone (2009) analyzed the data obtained from participants by dividing them into three in their study on sample of internal auditors in Italy. In the study, quality of internal audit procedures, characteristics of internal audit and outcomes of internal audit activity have been associated with IAE. According to results of the study, IAE is affected by characteristics of audit team, audit process and organizational relationships. IAE is measured by level of execution of the internal audit's recommendations by managers.

Alzeban \& Gwilliam (2014) examined relationship between IAE and five independent variables with multiple regression analysis on data collected from internal auditors and business managers working in Saudi Arabia. The results showed that support of management is variable that has the most positive effect on IAE. Similar studies have been suggested to be carried out especially in developing countries.

Drogalas et al. (2015) collected data from the participants consisting of employees of a few companies listed 
on the stock exchange in Greece in order to determine factors related to IAE. The findings of study showed that quality of internal audit activity, competence of audit team, independence of internal audit and support of management are main factors that positively affect IAE. The results of study reveal that independence of internal audit is the most prominent factor. In future studies, it has been proposed to test variables such as cooperation with external auditor or to examine opinions of different parties.

Coetzee \& Erasmus (2017) obtained a 92-item scale by applying exploratory factor analysis on data obtained from employees of public organizations operating in South Africa in order to determine variables that steer and measure IAE. In the study, the literature was reviewed to determine factors that steer IAE. The independent variables that are predicted to affect IAE in the literature are classified as separate structures. One of the prominent purposes of the study is to form basis for future studies. It has been suggested that the research methodology should be repeated in future studies for private sector.

Current issues affecting the business world have led to study of different variables in different periods. While the literature on IAE is more focused on characteristics of internal auditor, such as competence, independence and performance, then it has focused on relations with external auditor, senior management and board of directors. In the table below, a summary of prominent studies conducted for private sector in the literature on IAE is presented.

Table 1: Summary of literature on IA effectiveness in private sector companies.

\begin{tabular}{|c|c|c|c|c|}
\hline Year & Authors & Independent Variables & Method & Region \\
\hline 2003 & Al-Twaijry et al. & $\begin{array}{l}\text { Competence, Size/Structure of IAF, Management } \\
\text { Support, Independence, Scope of Work, } \\
\text { Organizational Characteristics }\end{array}$ & $\begin{array}{l}\text { Descriptive } \\
\text { Statistics }\end{array}$ & Saudi Arabia \\
\hline 2008 & Yee et al. & $\begin{array}{l}\text { Competence, IA and EA Relationships, Independence, } \\
\text { Quality Work/Measure Performance, Professional } \\
\text { Proficiency }\end{array}$ & $\begin{array}{l}\text { Descriptive } \\
\text { Statistics }\end{array}$ & Singapore \\
\hline 2009 & Arena \& Azzone & $\begin{array}{l}\text { Competence, Size/Structure of IAF, Organizational } \\
\text { Status/Characteristics }\end{array}$ & $\begin{array}{l}\text { Regression } \\
\text { Analysis }\end{array}$ & Italy \\
\hline 2010 & Cohen \& Sayag & $\begin{array}{l}\text { Management Support, Independence, Professional } \\
\text { Proficiency, Quality Work/Measure Performance }\end{array}$ & $\begin{array}{l}\text { Regression } \\
\text { Analysis }\end{array}$ & Israel \\
\hline 2011 & $\begin{array}{l}\text { Soh \& Martinov- } \\
\text { Bennie }\end{array}$ & $\begin{array}{l}\text { Competence, IA and EA Relationships, Organizational } \\
\text { Status/Characteristics, Size/Structure of IAF }\end{array}$ & Qualitative & Australia \\
\hline 2012 & Abu-Azza & $\begin{array}{l}\text { Competence, IA and EA/Other Relationships, } \\
\text { Management Support, Independence, Scope of } \\
\text { Work, Organizational Status/Characteristics }\end{array}$ & $\begin{array}{l}\text { Qualitative, } \\
\text { Descriptive } \\
\text { Statistics }\end{array}$ & Libya \\
\hline 2014 & Lenz et al. & $\begin{array}{l}\text { Competence, IA and EA Relationships, Management } \\
\text { Support, Organizational Status/Characteristics, Size } \\
\text { of IAF }\end{array}$ & Quantitative & Germany \\
\hline 2015 & Drogalas et al. & $\begin{array}{l}\text { Competence, Independence, Management Support, } \\
\text { Quality Work/Measure Performance }\end{array}$ & $\begin{array}{l}\text { Regression } \\
\text { Analysis }\end{array}$ & Greece \\
\hline 2015 & D’Onza et al. & $\begin{array}{l}\text { Competence, Management Support, Independence, } \\
\text { Professional Proficiency, Organizational Status/ } \\
\text { Characteristics }\end{array}$ & $\begin{array}{l}\text { Regression } \\
\text { Analysis }\end{array}$ & $\begin{array}{l}\text { Many } \\
\text { Countries }\end{array}$ \\
\hline 2016 & Salehi & $\begin{array}{l}\text { Competence, IA and EA/Other Relationships, } \\
\text { Size/Structure of IAF, Management Support, } \\
\text { Independence }\end{array}$ & $\begin{array}{l}\text { Regression } \\
\text { Analysis }\end{array}$ & Iran \\
\hline 2018 & Azzali \& Mazza & $\begin{array}{l}\text { Organizational Status/Characteristics, Scope of Work, } \\
\text { IA and EA/Other Relationships, Size/Structure of IAF }\end{array}$ & $\begin{array}{l}\text { Structural } \\
\text { Equation Model }\end{array}$ & Italy \\
\hline
\end{tabular}


Current approaches that impose responsibilities on internal auditors such as governance, internal control and risk management, which affect level of achieving business objectives, have influenced variables included in developed researching models. The perspective provided by the previous studies underlined that internal auditors and chief audit executives, as well as senior management, have responsibilities to ensure IAE. This perspective is aware of the responsibilities of all parties that strive to achieve objectives of business, which have an impact on IAE, and supports focus on the right areas. However, IAE is a dynamic workspace and should be supported by more future studies. The change in business environment directly affects internal audit, which is already a dynamic profession. IAE is directly affected by professional regulations and business needs. Although ISPPIA has adopted factors that have an impact on IAE as current standards for both organizations and internal auditors (IIA, 2018), number of comprehensive studies examining private sector companies operating in developing countries is limited. Previous studies emphasized precisely that new studies are needed. The present study will make a unique contribution to the literature, as it is first comprehensive experimental study that addresses Turkish private sector in the field of IAE.

\subsection{Independence of Internal Audit}

The first condition for IAE is to provide conditions that guarantee independence within organization. The definition of internal audit emphasizes that it is an independent and objective activity. The concept that is closely related to independence is objectivity (Stewart \& Subramaniam, 2010, 330). ISPPIA has defined independence as being free from conditions that threaten objectivity and objective appearance. Such a threat should be managed both at the level of internal auditor in individual context and at the level of internal audit department in the functional context. Independence is an inevitable requirement for internal audit profession. ISPPIA has expressed independence of internal audit as the most prominent indicator of IAE. Internal auditors should not have a position within their organization where their independence can be questioned and cannot continue their activities with their objective professional judgment (Vanasco, 1994).

Previous studies have tested opinions of participants on whether internal audit departments can achieve effectiveness in private sector organizations that do not have conditions that ensure independence of internal audit function (Yee et al., 2008; Cohen \& Sayag, 2010;
Abu-Azza, 2012; D'Onza et al., 2015; Drogalas et al., 2015). The results of previous studies have not been able to reach full consensus on whether independence is the most prominent factor in the effectiveness of internal audit. For example, Yee et al (2008) provided evidence that the independence of internal audit function is not the most prominent factor for IAE in the results of research that it restricted to Singapore private organizations. On the other hand, Drogalas et al (2015) discovered in their research in Greece that the most prominent factor affecting IAE is independence of internal audit department. Considering previous discussions, following hypothesis is formulated:

$\mathbf{H}_{1}$. Independence of internal audit positively affects IAE.

\subsection{Size of Internal Audit Department}

In order for internal audit to assume its responsibilities properly, it must first of all have a sufficient number of qualified staff (Arena \& Azzone 2009, 44). According to ISPPIA 2030, Chif Audit Executive is responsible for providing necessary, appropriate and sufficient resources for implementation of audit plan, effectively managing resources, reporting resource needs to senior management, and supporting senior management in resource allocation. As stated in Practice Advisory 20301 , one of the resources needed to fulfill internal audit responsibility is employment of a sufficient number of internal auditors.

The size of internal audit department greatly affects structure of internal audit function. While large internal audit department $s$ are more likely to have a more hierarchical management structure, auditors are more autonomous in small departments (Prawitt, 2003, 178). The fact that auditors will have to take on a wider range of different types of tasks in internal audit departments with insufficient staff indicates a potential hazard that threatens IAE. On the other hand, size of internal audit department directly affects time required for audit activity. In internal audit departments that do not have enough staff, auditors face time pressure to fulfill their duties on time. In addition, internal audit department, which has a sufficient number of staff, can rotate more auditors to achieve more objectivity. By rotating more auditors, conflicts of interest that damage auditor objectivity can be avoided.

Previous studies have shown that when there is a sufficient number of internal auditors, probability of internal audit's effectiveness is high. For example, the results of Salehi (2016) showed that research participants listed 
the fact that internal audit departments have sufficient number of internal auditors in Iranian private sector organizations among factors that positively affect IAE. Many studies show that there is a positive correlation between having sufficient number of internal auditors and performance of internal audit departments (Al-Twaijry et al., 2003; Soh \& Martinov-Bennie, 2011; Lenz et al., 2014). For example, Al - Twaijry et al. (2003) reported that the CAE of a company operating in Saudi private sector commented that relatively small internal audit departments were unable to perform all tasks, neglected many tasks, and focused only on a broad perspective. Based on previous discussions, following hypothesis is formulated:

$\mathbf{H}_{\mathbf{2}}$. The size of internal audit department positively affects IAE.

\subsection{Competence of Internal Audit}

Technical competence is essential for effectiveness of internal audit function (Mihret et al. 2010). The standards published by IIA demand competence of internal auditors. ISPPIA 1210 states that internal auditors must have knowledge, skills and other competencies required to fulfill their individual responsibilities. In addition, it is one of the leading responsibilities of top managers to equip internal audit departments with competencies required to fulfill their responsibilities collectively or acquire them. Many academic studies (Messier \& Schneider 1988; Maletta, 1993; Selim \& Mcnamee, 1999) have confirmed that competence is an prominent component of internal audit.

According to ISPPIA 1230, it is imperative that internal auditors develop their competencies through continuous professional development. Internal auditors must take into account continuous professional development in order to have the competencies needed to sustain their activities in a changing business environment (Selim \& Mcnamee, 1999). In order for the internal audit profession to assume new roles in risk management and corporate governance, internal auditors need to create a new set of skills (Arena \& Azzone 2009). In addition, the internal auditors are expected to have the knowledge and skills to assume responsibilities that do not conflict with the characteristics of their profession in areas such as corporate risk management, governance, compliance and information technologies (Onay \& Erdoğan, 2019).

According to Al - Twaijry et al., (2003), competence of staff and managers of internal audit departments is vital to effective functioning of internal audit activities, and if they do not have necessary competence, IAE will decrease. When internal auditors do not have sufficient knowledge and skills, their recommendations are ignored by senior management and IAE is damaged (Peursem, 2005). On the other hand, competence of internal audit is one of the most prominent criteria that affect the level of trust of external auditors in internal audit activities (Gramling et al., 2004; Al-Twaijry et al., 2004; Lenz et al., 2018). Previous studies (Yee et al., 2008; Arena \& Azzone 2009; Soh \& Martinov-Bennie, 2011; D'Onza et al., 2015; Drogalas et al., 2015) have focused on competence of internal audit departments as one of the criteria that internal audit function should have in order to achieve high efficiency in private sector organizations. For example, Arena \& Azzone (2009) determined that insufficient knowledge and skills of internal auditors in Italy private sector companies had a negative impact on IAE. In accordance with existing support in the literature, following hypotheses have been formulated:

$\mathbf{H}_{3}$. The competence of internal audit positively affects IAE.

\subsection{Management Support}

Internal audit, which is positioned as strategic mind co-partner of senior management in organizational hierarchy of enterprise, must be supported by management in order to maintain its activities with optimum performance. Senior management is responsible for establishing conditions that allow the internal audit function to perform its duties within the organization. The ability of internal audit to maintain its independence depends on meeting these conditions, that is, on support of management. The prominence of the relationship between internal audit and senior management is clear in determining independence and objectivity of internal auditor (Al-Twaijry et al. 2003). The support of senior management therefore plays a vital role in effectiveness of audit process. Internal audit managers and auditors should gain support of senior management in order to improve audit effectiveness. Support of senior management and board of directors for internal auditing is developed with relationships based on mutual trust and significant interaction (IIA, 2018).

Previous studies (Cohen \& Sayag 2010; Lenz et al., 2014; Drogalas et al. 2015; D'Onza et al., 2015) confirmed that IAE depends on support of management. Albrecht et al. (1988) argue that open support of management is variable that has the greatest impact on IAE. According 
to Sarens \& De Beelde (2006), internal audit needs support of senior management in order to gain the general acceptance and recognition of its organizational structure. For this, internal audit should try to gain support of management by showing its potential to add value to organization. Cohen \& Sayag (2010) determined the prominence of senior management's support in their research in Israel organizations to discover factors of IAE. It has been emphasized that decisions such as recruitment of specialized internal auditors, providing career opportunities for audit staff and providing organizational independence to audit activities have a positive effect on IAE. Arena and Azzone (2009) measured IAE based on how well recommendations were taken into account by senior management. Sarens \& De Beelde (2006) classified implementation of internal audit's recommendations by senior management as one of the indicators of management support for internal audit. Lenz \& Hahn (2015) has confirmed that relationship between internal audit and management, which is its principal client, is still an area of study that is worth investigating. The lack of empirical studies reflecting situation in this field, especially in developing countries, is one of the motivations of our study. With this motivation, following hypothesis is formulated:

\section{$\mathbf{H}_{4}$. Management support positively affects IAE.}

\subsection{Cooperation with External Auditor}

Together with internal and external audit, audit committee and senior management, they are considered as the four basic cornerstones of corporate governance. Internal and external audit are leading representatives of business stakeholders (Gramling vd., 2004, s. 196). They fight together against danger of moral hazard and adverse selection caused by information asymmetry and conflict of interest between managers and stakeholders (Jensen \& Meckling, 1976). Internal auditors and external auditors should be in coordination in their activities, respect each other and make use of each other's abilities (Sawyer vd., 2005, s.8). By improving coordination and cooperation among internal and external auditors, they can both increase effectiveness and efficiency of audit activities and benefit from each other's work (Wood, 2004: 2). When client business has an effective internal audit function, external auditors can identify control risk low and narrow scope of their testing. Based on performance of internal auditors in audit tests, external auditors can complete their audit in less time and at less cost. Because of activity advantages provided by effective cooperation between the parties, audit costs and therefore audit fees are reduced when external auditors deem it appropriate to benefit from internal audit activities (Felix et al., 2001; Wood, 2004; Suwaidan \& Qasım 2010; Mat Zain et al., 2015).

Many professional standards guide cooperation and coordination between internal and external audit. ISA 610 (2013) published by IFAC and SAS 65 (1991) published by AICPA guide external auditors when they plan to benefit from direct assistance or work of internal audit function to narrow scope of their audit procedures. ISPPIA 2050-1 (2013), published by IIA, guides internal auditors to prevent unnecessary repetition of same work when collaborating with the external auditor. As stated, professional standards emphasize the contribution that internal and external audit can provide to each other. Coordination and cooperation between the two functions positively affects IAE. Time and resource savings by reducing unnecessary repeated efforts create opportunities for internal auditors to focus on other responsibilities. Many academic studies have confirmed that lack of coordination between internal and external auditors and absence of collaboration affects performance of internal audit in the private sector organizations of developing countries negatively. Moreover, studies in the literature (Yee et al., 2008; Soh \& Martinov-Bennie, 2011; Abu-Azza, 2012; Lenz et al., 2014) have determined that collaboration with external auditor increases IAE in private sector enterprises. For example, Abu-Azza (2012) reported that majority of internal audit managers in Libya organizations have view that collaboration with external auditors is beneficial for internal audit. With the orientation of previous studies, following hypothesis is formulated:

$\mathbf{H}_{5}$. Cooperation with external auditor positively affects IAE.

\subsection{Risk Management Activities}

Internal audit is a function that serves organization. IAE is a risk-based concept that contributes to organization's achievement of its purposes by improving corporate governance quality. An effective internal audit function is expected to review key risk areas to contribute to organization's purposes (Lenz \& Hahn, 2015 , s.7). Corporate governance is included in definition of internal audit as an umbrella concept that covers risk management and internal control. Corporate management and risk management saddle internal audit function with a responsibility of being a part of their activities to ensure its organization achieves its purposes. IIA's position reports and current COSO Enterprise Risk 
Management Framework require a risk-based internal audit. IAE in today's complex business environment is associated with ability to assume these responsibilities. The effectiveness of internal audit function becomes possible only when audit activities are conducted on a risk-based basis. As a result, success level of internal audit function's contribution to organization is directly related to its impact on enterprise risk management.

Modern internal audit activities must be carried out on a risk-based basis. Internal audit should be at center of potential threats and problems facing its organization. It is supported by the literature that being a part of enterprise risk management and that internal audit activities focus on more risky and prominent issues has a positive effect on its effectiveness (Allegrini \& D'Onza, 2003; Spira \& Page, 2003; Sarens \& De Beelde, 2006; Arena \& Azzone, 2009; Castanheira et al. 2010; Sarens et al., 2012; Coetzee \& Lubbe, 2013; Lenz \& Hahn, 2015). Sarens \& De Beelde (2006) reported that risk-based internal audit activities increased effectiveness of internal audit function in qualitative study they conducted on Belgian and American companies. Participants of their study stated that internal auditors are worried about effectiveness of internal audit in cases where internal auditors are not able to participate adequately with increase of their enterprise risk management activities (2006, p.76). Castanheira et al. (2010) stated that lack of risk-oriented conduct of internal audit activities in many private sector enterprises caused negative results. It can be said that more internal audit function contributes to control of primary risks to which organization is exposed, more it increases its effectiveness. In the light of previous studies in the literature, final hypothesis is formulated:

$\mathrm{H}_{6}$ Carrying out risk-based activities of internal audit positively affects its effectiveness.

\section{Methodology}

\subsection{Population and Sample of the Study}

Our study population working in the private sector company in Turkey and is also designated as internal auditors who are members of IIA-Turkey. According to the annual report 2019, IIA-Turkey has 2731 members. By reaching entire target universe during data collection process, internal auditors willing to participate in our research were contacted. The questionnaire forms were sent to target population by e-mail three times at two-month intervals. In addition, in order to increase number of participants, many internal auditors were contacted face to face and via telephone. This process was completed between second half of 2019 and first quarter of 2020.

At the end of data collection process, 194 participants were provided to answer our questionnaire. In calculating sufficient sample size, $n>50+8 m$ (where $m$ $=$ number of variable) formula is recommended (Tabachnick \& Fidell, 2013). Since there were 7 variables in our research model, 187 participants were found sufficient. Demographic characteristics of our participants are presented in Table 2.

Table 2: Professional demographics of the participants.

\begin{tabular}{|c|c|c|c|}
\hline & & Frequency & Percentage \\
\hline \multirow{2}{*}{ Gender } & Female & 83 & $44 \%$ \\
\hline & Male & 104 & $56 \%$ \\
\hline \multirow{4}{*}{ Age } & 37 and less & 50 & $27 \%$ \\
\hline & Between 38-44 & 45 & $24 \%$ \\
\hline & Between 45-53 & 51 & $27 \%$ \\
\hline & 54 and more & 41 & $22 \%$ \\
\hline \multirow{5}{*}{$\begin{array}{l}\text { Number } \\
\text { of internal } \\
\text { auditors in } \\
\text { the IAD }\end{array}$} & 3 and less & 54 & $29 \%$ \\
\hline & Between 4-5 & 25 & $13 \%$ \\
\hline & Between 6-9 & 44 & $24 \%$ \\
\hline & Between 10-12 & 30 & $16 \%$ \\
\hline & 13 and more & 34 & $18 \%$ \\
\hline \multirow{4}{*}{$\begin{array}{l}\text { Work } \\
\text { Experience }\end{array}$} & 4 and less & 55 & $29 \%$ \\
\hline & Between 5-8 & 44 & $24 \%$ \\
\hline & Between 9-15 & 52 & $28 \%$ \\
\hline & 16 and more & 36 & $19 \%$ \\
\hline
\end{tabular}

\subsection{Measurement Tool Development}

In the process of compiling measurement tool of our study, opinions of 10 academicians working in the field of internal audit and 10 internal auditors with a high level of professional experience were consulted. First of all, a comprehensive pool of 173 items was formed, consisting of expressions that are included in questionnaires used in many studies (Arena \& Azzone 2009; Cohen \& Sayag 2010; Alzeban \& Gwilliam 2014; Drogalas et al. 2015; Salehi 2016; Endaya \& Hanefah 2016; Coetzee \& Erasmus 2017) dealing with IAE, and suggested by the authors of present study as a result of detailed literature review. Then, an item pool assessment study was conducted with field experts consisting of academicians and internal auditors. The question items cannot serve purposes of the study if there is an 
insufficient reflection of concept under investigation or if it goes beyond its limits (DeVellis, 2003, s.64). Each question item was evaluated by the specialist team in terms of how suitable it was for purposes of the study and its understandability.

The extent to which the measurement tool or each item serves purposes of the study is expressed as content validity. Lawshe (1975) technique was used to determine the content validity. In this technique, content validity ratios (CVR) are obtained from opinions of the specialist regarding any item. The content validity ratio of an item is calculated by the following formula: $\operatorname{CVR}=\frac{\mathrm{N}_{\mathrm{A}}-(\mathrm{N} / 2)}{\mathrm{N} / 2} \cdot \mathrm{N}$ indicates the total number of specialist, and indicates the number of specialist who express an appropriate opinion on the item.

Significance of items is tested with statistical criteria. As in our study, with data obtained from 20 experts, the lowest acceptable value for an evaluation at level of $\alpha=0.05$ significance is 0.42 (Veneziano \& Hooper, 1997). Items below this value are removed from the measuring tool. As a result of the item pool assessment study, question statements whose consensus statistics were below the threshold value were eliminated and a questionnaire consisting of 39 items was obtained. The content validity index of obtained questionnaire is 0.86 . This ratio shows that the questionnaire is suitable for purposes of the study and has high comprehensibility.

\subsection{Measurement of Variables}

In the design of questionnaire, which is measurement tool of our study, the factors that negatively affect data collection were taken into consideration. An optimum balance should be established between number of items in questionnaire and the sample size that is intended to be reached (Fowler, 1995). For this, variables of our research model were measured with an optimum number of questions. Five point likert type rating scale was preferred in design of the questionnaire ( $1=$ strongly disagree to $5=$ strongly agree). In addition, there are four open-ended questions in our measurement tool aiming to determine number of auditors that internal audit departments has and demographic characteristics of participants such as gender, age and professional experience. The variables in our model were measured by analyzing answers of internal auditors to questions in measurement tool. The question statements included in the questionnaire for measuring each variable are listed below.

Internal Audit Effectiveness (IAE): The dependent variable of our model was measured with 10 items: (1)
IA ensure that it adds value to the business. (2) IA improves organizational performance. (3) IA determines adequacy and effectiveness of organization's control systems. (4) IA evaluates the accuracy and reliability of financial reports. (5) IA reviews compliance with policies, plans, procedures and regulations. (6) IA reviews means of safeguarding assets. (7) IA reviews economical, effective and efficient use of resources. (8) Recommendations in the internal audit report are implemented in a timely manner. (9) IA develops controls to ensure that corrective actions are implemented and effective. (10) Suggestions put forward by internal auditors are largely implemented.

Independence of Internal Audit (IND): This variable was measured with 7 items: (1) Internal auditors can submit their reports from bottom to senior management in organization. (2) Internal auditors can freely audit all departments within the organization and specifically employees without additional permissions and can examine related documents. (3) Internal auditors have the indispensable independence to fulfill their professional obligations and duties. (4) Internal auditors are exposed to the intervention of top management while conducting their audits. (Reverse Scored). (5) The chief audit executive has first-hand contact to board of directors. (6) Internal auditors are not required to perform work that does not relate to their profession. (7) Terminating work of internal audit requires approval of audit committee, and/or board of directors.

The Size of Internal Audit Department (SIZE): This continuous independent variable was measured through an open-ended question to determine number of internal auditors.

Competence of Internal Audit (COMP): This variable was measured with 6 items: (1) The professional knowledge of internal auditors is at the level to fulfill their responsibilities in the best way. (2) Internal auditors attend educational seminars for continuous training. (3) Internal auditors have sufficient professional qualifications to perform mandatory and voluntary rotations. (4) The vast majority of internal auditors have necessary certifications such as CIA, CFE and CPA. (5) Internal audit function has right mix of competencies in areas of expertise such as data security, taxation, audit software, new business technologies. (6) Internal auditors have relevant training that enables them to audit all systems of the organization.

Management Support (MS): This variable was measured with 5 items: (1) Top management supports 
internal audit to fullfil its tasks and liabilities. (2) IA function has the financial resources required for its audit-related tasks. (3) The response to internal audit reports by senior management is reasonable. (4) Senior management has open communication with chief audit executive. (5) IA function employs the necessary number of auditors and employees to undertake its tasks.

Cooperation with External Auditor (CEA): This variable was measured with 7 items: (1) There is effective communication between internal and external audit. (2) External auditors are tolerant and positive towards internal auditors. (3) External auditors allow internal auditors to express concerns about audit work. (4) External and internal auditors reach a consensus on the timing of their work in the areas they cooperate for their common interests. (5) External auditors discuss their audit plans with internal auditors. (6) External auditors meet regularly with internal auditors. (7) Both external and internal auditors make their working papers available to each other.

Involvement of internal audit in Risk Management (RM): This variable was measured with 4 items: 1) IA strives to improve risk management and evaluates its effectiveness. (2) A considerable part of work of internal auditors consists of risk assessment activities. (3) Internal auditors implement control risk self-assessment techniques (CRSA). (4) IA determines whether the organization's risk responses match the risk appetite.

\subsection{Data Analysis}

Before applying statistical analysis, the normality that was prerequisite for both factor analysis and regression analysis was tested. Kolmogorov-smirnov test statistics that measure normality, skewness-kurtosis values and histogram graphs show that our data shows normal distribution and normality assumption is not violated.

Firstly the principle component analysis (PCA) was applied in order to obtain factors consisting of a more steerable number of the data obtained with measurement tool prepared to measure dependent and independent variables in our research model. By means of PCA analysis, measurable and observable items are gathered under a small number of variables that are not directly observable, while the construct validity of our questionnaire is measured. In addition, internal consistency, which is the degree to which the expressions in the data compilation tool can measure the same intended feature for each measurement, is an prominent indicator of reliability and has been tested with the Cronbach Alpha (CA) coefficient. PCA was preferred to obtain an empirical summary of the experiment set for use in subsequent analysis (Stevens, 1996, p.363) and to overcome problems arising from factor uncertainty (Tabachnick \& Fidell, 2013, p.640). For the factor rotation, promax was carried out from oblique approaches acting with the assumption that there was a correlation between variables. The factors obtained as a result of this analysis are defined as the variables of multiple regression analysis carried out later.

Before testing our model on which we tested effect of independent variables on IAE, the assumptions of multiple regression were checked. In addition to normal distribution, it has been confirmed that multicollinearity and singularity assumptions are not violated and have sufficient sample size. As stated earlier, outliers were eliminated at beginning of data scanning process. Ordinary least squares (OLS) multiple regression was performed to test our hypotheses that deal with relationship between IAE, which is the dependent variable of our model, and six predictive variables we discussed in detail in the previous section.

\section{Findings and Discussion}

\subsection{Principle Component Analysis}

The results obtained from Kaiser-Meyer-Olkin (KMO) and Bartlett tests evaluating the suitability of the data for factor analysis were interpreted before PCA was performed in order to reveal factor structures of scale and to measure construct validity. The $p<0.001$ significance level was calculated as KMO Value 0.957 and Bartlett Value 6517. The calculated values show that the datas are suitable for factor analysis. In order to reach the most suitable factor structure, factor extraction criteria were taken into consideration while making analyzes. According to this; (1) only factors with eigenvalues above 1 were retained, (2) items with factor loads less than 0.50 were excluded, and (3) having higher loads under more than one factor, and those with a difference below 0.10 items were removed from the scale. Five items (IAE5, IND4, COMP5, CEA5, CEA6) were removed from the measurement tool, taking into account the factor extraction criteria. As a result of the analyzes, six interpretable factors explained $78 \%$ of total variance were obtained.

Factors consisting of items related to each other were named in a manner consistent with the model 
of our research. According to this, the first factor explained $52 \%$ of the variance is named as "internal audit effectiveness". The second factor explained $9 \%$ of the variance is named as "independence". The third factor explained $5 \%$ of the variance is termed "risk management", the fourth factor explained $5 \%$ of the variance is termed "collaboration with the external auditor" and the fifth factor explained $4 \%$ of the variance is termed "competence". The last factor included five items that explained $3 \%$ of the variance is named as "management support". Descriptive statistics of the items, factor loads, Cronbach's Alpha coefficients and explained variance rates are shown in Table 3.

Table 3: Descriptives statistics and factor structure

\begin{tabular}{|c|c|c|c|c|c|c|}
\hline Factor & Item & Mean & SD & Loading & Cronbach's Alpha & Explained Variance (\%) \\
\hline \multirow{9}{*}{$\begin{array}{l}\text { Internal Audit } \\
\text { Effectiveness (IAE) }\end{array}$} & IAE3 & 4,18 & 0,717 & 0,884 & \multirow{9}{*}{0,947} & \multirow{9}{*}{51,56} \\
\hline & IAE7 & 4,05 & 0,774 & 0,865 & & \\
\hline & IAE1 & 4,18 & 0,710 & 0,846 & & \\
\hline & IAE4 & 4,18 & 0,700 & 0,802 & & \\
\hline & IAE9 & 4,17 & 0,698 & 0,793 & & \\
\hline & IAE2 & 4,23 & 0,720 & 0,783 & & \\
\hline & IAE6 & 4,23 & 0,684 & 0,742 & & \\
\hline & IAE10 & 4,13 & 0,744 & 0,732 & & \\
\hline & IAE8 & 4,21 & 0,679 & 0,730 & & \\
\hline \multirow{6}{*}{ Independence of IA (IND) } & IND2 & 3,99 & 0,741 & 0,919 & \multirow{6}{*}{0,957} & \multirow{6}{*}{8,808} \\
\hline & IND1 & 4,01 & 0,748 & 0,913 & & \\
\hline & IND5 & 4,04 & 0,736 & 0,893 & & \\
\hline & IND6 & 4,00 & 0,726 & 0,881 & & \\
\hline & IND7 & 3,98 & 0,758 & 0,848 & & \\
\hline & IND3 & 4,00 & 0,751 & 0,841 & & \\
\hline \multirow{4}{*}{$\begin{array}{l}\text { Risk Management } \\
\text { Activities of IA (RM) }\end{array}$} & $\mathrm{RM} 3$ & 3,91 & 0,781 & 0,964 & \multirow{4}{*}{0,979} & \multirow{4}{*}{5,422} \\
\hline & $\mathrm{RM} 1$ & 3,92 & 0,796 & 0,960 & & \\
\hline & $\mathrm{RM} 2$ & 3,93 & 0,804 & 0,951 & & \\
\hline & RM4 & 3,94 & 0,794 & 0,949 & & \\
\hline \multirow{5}{*}{$\begin{array}{l}\text { Cooperation between } \\
\text { IA and external auditors } \\
\text { (CEA) }\end{array}$} & CEA7 & 3,94 & 0,756 & 0,850 & \multirow{5}{*}{0,905} & \multirow{5}{*}{4,857} \\
\hline & CEA3 & 3,85 & 0,809 & 0,799 & & \\
\hline & CEA4 & 3,85 & 0,789 & 0,788 & & \\
\hline & CEA1 & 3,87 & 0,775 & 0,781 & & \\
\hline & CEA2 & 3,87 & 0,826 & 0,774 & & \\
\hline \multirow{5}{*}{$\begin{array}{l}\text { Competence of IA } \\
\text { (COMP) }\end{array}$} & COMP4 & 4,01 & 0,779 & 0,931 & \multirow{5}{*}{0,898} & \multirow{5}{*}{4,389} \\
\hline & COMP1 & 3,98 & 0,718 & 0,819 & & \\
\hline & COMP3 & 3,93 & 0,729 & 0,800 & & \\
\hline & COMP2 & 4,01 & 0,726 & 0,762 & & \\
\hline & COMP6 & 3,98 & 0,729 & 0,733 & & \\
\hline \multirow{5}{*}{$\begin{array}{l}\text { Management Support for } \\
\text { IA (MS) }\end{array}$} & MS3 & 4,01 & 0,773 & 0,920 & \multirow{5}{*}{0,933} & \multirow{5}{*}{3,246} \\
\hline & MS2 & 3,99 & 0,783 & 0,853 & & \\
\hline & MS1 & 4,02 & 0,776 & 0,793 & & \\
\hline & MS4 & 4,06 & 0,798 & 0,772 & & \\
\hline & MS5 & 4,00 & 0,786 & 0,711 & & \\
\hline
\end{tabular}

KMO: 0.957; Bartlett: 6517; Total Variance explained: \%78 
The average scores of each statement in the questionnaire are included in Table 3. The average scores obtained with the five-point likert scale show that level of participation in statements of independent variables is approximately 4 and level of participation in statements of the dependent variable (IAE) is slightly above 4. Statements for each variable have averages close to each other. It is understood from the averages of statements that perception of participants in the Turkish private sector firms regarding IAE audit and related variables is quite high. Average scores are higher than those obtained in many similar studies in developing countries (Arena \& Azzone, 2009; Cohen \& Sayag, 2010; Alzeban \& Gwilliam 2014; D'Onza et al., 2015; Drogalas et al., 2015; Coetzee \& Erasmus, 2017).

The CA coefficient calculated to determine how compatible statements in measurement tool perform together is presented in Table 3. IAE variable consisting of 9 items has 0.947 , IND variable consisting of 6 items has 0.957 , RM variable consisting of 4 items has 0.979 , CEA variable consisting of 5 items has 0.905 , COMP variable consisting of 5 items has 0.898 , and MS variable consisting of 5 items has 0.933 CA reliability coefficient. CA coefficients calculated for variables indicate a high level of reliability.

\subsection{Regression Analysis}

The hypotheses developed in the previous section were tested with the following regression model:

$$
\begin{aligned}
& \mathrm{IAE}=b_{0}+b_{1} \mathrm{SIZE}+b_{2} \mathrm{IND}+b_{3} \mathrm{COMP} \\
& +b_{4} \mathrm{MS}+b_{5} \mathrm{CEA}+b_{6} \mathrm{RM}+e_{i}
\end{aligned}
$$

In order to obtain reliable results from the regression analysis, it is desirable to have a correlation of more than 0.30 , preferably between dependent and independent variables, while a very high correlation level of more than 0.90 between independent variables leads to a multicollinearity problem (Pallant, 2016). Firstly correlation analysis was performed in order to evaluate that independent variables of the model are related to dependent variable at least to a certain level and the probability of multicollinearity problem arising. Correlation between variables is presented in Table 4 . Correlation was determined between IAE dependent variable and all independent variables except SIZE. In addition, a high correlation was found among all other independent variables except SIZE. However, the correlation level is among the acceptable limits mentioned above.

\begin{tabular}{|c|c|c|c|c|c|c|c|c|c|}
\hline Variables & Mean & SD & 1 & 2 & 3 & 4 & 5 & 6 & 7 \\
\hline $1 \mathrm{IAE}$ & 4,174 & 0,598 & 1 & & & & & & \\
\hline 2 SIZE & 7,818 & 5,131 & 0,076 & 1 & & & & & \\
\hline 3 IND & 4,005 & 0,674 & $0,689^{*}$ & 0,105 & 1 & & & & \\
\hline 4 COMP & 3,981 & 0,621 & $0,674^{*}$ & 0,059 & $0,620^{*}$ & 1 & & & \\
\hline $5 \mathrm{MS}$ & 4,014 & 0,696 & $0,745^{*}$ & 0,031 & $0,681^{*}$ & $0,596^{*}$ & 1 & & \\
\hline 6 CEA & 3,876 & 0,674 & $0,623^{*}$ & $-0,079$ & $0,618^{*}$ & $0,577^{*}$ & $0,655^{*}$ & 1 & \\
\hline $7 \mathrm{RM}$ & 3,924 & 0,769 & $0,489^{*}$ & 0,135 & $0,365^{*}$ & $0,278^{*}$ & $0,432^{*}$ & $0,444^{*}$ & 1 \\
\hline
\end{tabular}

Table 4: Correlation coefficients for the variables in the model.

$\mathrm{N}=187 *$ Correlation is significant at the .01 level.

To determine whether a multicollinearity problem exists, tolerance value and variance inflation factor (VIF) are commonly used criterias. These criterias have been examined to evaluate the possibility of multicollinearity in depth. To ensure that the regression results are not overshadowed by multicollinearity problem, tolerance values must be above 0.10 and VIF value below 2.5 or at least 4 (Pallant, 2016; Hair et al., 2010). The tolerance and VIF values, which are among the acceptable limits presented in Table 5, support that regression analysis results are not suspected due to multicollinearity. 
Table 5: Results of regression analysis

\begin{tabular}{llllllll}
\hline Variable & $\mathrm{B}$ & Std. Error & $\beta$ & $t$ & $p$-value & Tolerance & VIF \\
\hline Constant & 0,558 & 0,190 & & 2,929 & 0,004 & & \\
SIZE & 0,001 & 0,005 & 0,009 & 0,201 & 0,841 & 0,924 & 1,082 \\
IND & 0,170 & 0,056 & $0,191^{* *}$ & 3,021 & 0,003 & 0,432 & 2,314 \\
COMP & 0,265 & 0,055 & $0,275^{* *}$ & 4,804 & 0,000 & 0,528 & 1,892 \\
MS & 0,300 & 0,056 & $0,349^{* *}$ & 5,397 & 0,000 & 0,415 & 2,407 \\
CEA & 0,037 & 0,056 & $0,041^{*}$ & 0,660 & 0,510 & 0,444 & 2,251 \\
RM & 0,134 & 0,038 & $0,173^{* *}$ & 3,569 & 0,000 & 0,742 & 1,348 \\
\hline
\end{tabular}

Predictors: (constant), size of the IAD, independence of IA, competence of IA, management support for IA, cooperation between IA and external auditors, risk management activities.

$R=0,829 ; R^{2}=0,688 ;$ Adjusted $R^{2}=0,677 ; F=66,085 ;{ }^{*} p \leq 0.1 ;{ }^{* *} p \leq 0.01$

The regression analysis results in Table 5 provide a comprehensive and precise review of the our research's hypotheses. Ordinary least squares (OLS) multiple regression was used to assess ability of six independent variables to predict IAE. A statistically significant effect of SIZE variable on the dependent variable could not be determined. It was determined that IND, COMP, MS, RM independent variables had statistically effect on the dependent variable at the level of $p \leq 0.01$ significance. In addition, it was found that CEA had a statistically effect on IAE at the level of $p \leq 0.10$ significance. $68.8 \%$ of the total variance related to IAE dependent variable was explained by the independent variables. Variance explanation rate corrected according to degree of freedom was measured as $67.7 \%$. It is determined that rate of dependent variable is explained by independent variables at a high level.

The value of $\mathrm{F}=66.085$ reached by ANOVA test evaluating significance of the model as a whole was found statistically significant at the level of $p<.001$. The significance of the $F$ value in Table 5 confirms that independent variables in the regression model generally explain IAE. In other words, IAE can be explained in a meaningful way with independent variables included in the model.

The findings obtained as a result of the analysis of the regression model showed that the most contributing factor to IAE is the support of the management. Management support is the primary factor in determining IAE. Because the potential factors that are expected to have an impact on IAE are theoretically dependent on management support (Sarens \& De Beelde, 2006). The findings obtained in the research definitely support this situation. On the other hand, the findings confirm that the independence and competence of internal audit has a strong influence on IAE. The high significance of these two variables has empirically demonstrated that the two theoretically necessary features of internal audit have a strong influence on IAE. International standards strongly emphasize the importance of independence and competence in conducting an effective internal audit activity (Prawitt, 2003). In addition, significant positive results were obtained in terms of RM and COMP variables included in the model to determine how to carry out the internal audit activity more effectively in practice. These findings show that internal audit is an activity that should be carried out with a focus on risk management in today's risk-surrounded business environment, and cooperation with the external auditor should be ensured in order to obtain benefits such as not repeating the same efforts unnecessarily. Finally, no relationship has been found between the number of auditors working in the internal audit department and IAE. This finding can be interpreted as the qualitative characteristics of internal audit are much more important than quantity, when the whole model is taken into account.

\section{CONCLUSION}

The founder of modern Turkey, Mustafa Kemal Ataturk's reforms, have today reached a different level of economic and cultural development of Turkey in the Middle East. After the proclamation of republic in 1923 , the value given to science and rational thought is basic cause of gaining different specifications from other countries in the region. The results of our research have made a unique contribution to existing literature by revealing the factors that determine IAE in a country with characteristics of Western and Eastern civilization. A role model for developing countries with many features that our research conducted in Turkey, offers 
unique results for academics and practitioners. This study completed a missing piece of the international literature mosaic on IAE.

In this study, independent variables, which are estimated to have an impact on IAE in previous studies, are examined on the sample obtained from Turkish private sector organizations. These are the variables of independence of internal audit, necessary professional competence of internal auditors, support of management for internal audit, cooperation with external auditor, number of auditors working in internal audit department and participation of internal auditors in risk management activities. The results revealed that the most prominent driving force of IAE is management support. The results of the study showed that the factors that have the greatest impact on the of IAE after management support are competence, independence, participation in risk management activities, and collaboration with external auditor, respectively. On the other hand, the number of auditors working in the internal audit department has no effect on IAE. When this finding is evaluated together with the finding that competence is one of the most prominent variables explaining $I A E$, it is concluded that quality is more prominent than quantity in terms of human resources in internal audit units of Turkish private sector organizations.

The results of the study showed that two variables with the most positive support on IAE are management support and independence. This result is compatible with previous studies. In many of the previous studies (Mihret \& Yismaw, 2007; Yee et al., 2008; Cohen \& Sayag, 2010; Alzeban \& Gwilliam 2014; Drogalas et al., 2015), the most influential variable was management support or independence. Again, as in our study, these two variables have positive correlations with other variables in most previous studies. ISPPIA and IIA reports have determined the independence of internal audit and management support as indispensable factors for internal audit activities to be carried out as desired. Internal Audit should have an organizational status that can carry out its activities objectively, and it should be able to make its decisions unaffected, including management, and also gain management support in order to obtain access to the resources it needs to carry out its activities and to avoid audit restrictions within the organization.

Collecting research data through questionnaire causes some methodological limitations by nature. IAE and related independent variables were measured through responses of participants to the questionnaire. Participants may tend to convey different opinions than they actually are. Although making the data collection process more difficult, measuring variables in research model with more provable indicators other than opinions of participants will weaken these limitations. The average of responses given to the questionnaire is higher than that obtained in many similar studies on samples from developing countries (Arena \& Azzone, 2009; Cohen \& Sayag, 2010; Alzeban \& Gwilliam 2014; D’Onza et al., 2015; Drogalas et al., 2015; Coetzee \& Erasmus, 2017). These findings differ from other countries to status of internal audit in Turkey and explained by showing the development of internal audit activities over the years. On the other hand, the fact that participants of our research consist only of internal auditors reveals possibility of bias. It is natural that internal auditors offering audit services tend to see their activities positively. This bias can be eliminated by repeating our research on participants who received audit services in future studies.

In this study, internal audit departments of private sector organizations in a developing country, which has characteristics of both western and eastern culture, were examined. When considering Turkey's unique economic and cultural characteristics, the results of the study show it is clear that future studies with similarity. This includes future studies in both developing countries in the Middle East and developed countries of Europe. Limited literature on IAE should be enriched with future research that examines private or public sector in both developed and developing countries. In addition, the limitations of our research in terms of the selection of model variables can be eliminated by including different variables that affect internal audit in the model. As a result of the item pool assessment study, the questionnaire obtained in our research can be used completely or partially according to selection of variables in future research.

Despite the many limitations mentioned earlier, this study has revealed relationship between IAE in Turkish private sector organizations and the most emphasized factors in previous studies and ISPPIA. Internal audit is an virgin area with a large number of research questions, which requires more scientific research. This study was supported by the international literature with an example from Turkey. This study supports more research from Turkey and other developing countries from having the potential to overcome its own limitations. 


\section{References}

Abu-Azza, W. (2012). Perceived effectiveness of the internal audit function in Libya: A qualitative study using institutional and Marxist theories. University of Southern Queensland, Australia (unpublished $\mathrm{PhD}$ dissertation).

Ahmad, N., Othman, R., Othman, R., \& Jusoff, K. (2009). The effectiveness of internal audit in Malaysian public sector. Journal of Modern Accounting and Auditing, 5(9), 53-62.

Allegrini, M. \& D’Onza, G. (2003). Internal auditing and risk assessment in large Italian companies: an empirical survey. International Journal of Auditing, 7(3), 191-208.

Al-Twaijry, A. M., Brierley, J. A., \& Gwilliam, D. R. (2003). The development of internal audit in Saudi Arabia: An institutional theory perspective. Critical Perspectives on Accounting, 14, 507-531.

Al-Twaijry, A., Brierley, J., \& Gwilliam, D. (2004). An examination of the relationship between internal and external audit in the Saudi Arabian corporatesector. Managerial Auditing Journal, 19(7), 929-944.

Alzeban, A. \& Gwilliam, D. (2014). Factors affecting the internal audit effectiveness: A survey of the Saudi public sector. Journal of International Accounting, Auditing and Taxation, 23(2), 74-86.

American Institute of Certified Public Accountant (AICPA) (1991). The Auditor's Consideration of the Internal Audit Function in an Audit of Financial Statements. Statement on Auditing Standards No. 65. New York: AICPA.

Arena, M., \& Azzone, G. (2009). Identifying organizational drivers of internal audit effectiveness. International Journal of Auditing, 13(1), 43-60.

Azzali, S., \& Mazza, T. (2018). The Internal Audit Effectiveness Evaluated with an Organizational, Process and Relationship Perspective. International Journal of Business and Management, 13(6), 238-254.

Castanheira, N., Rodrigues, L.L. \& Craig, R. (2010). Factors associated with the adoption of risk-based internal auditing. Managerial Auditing Journal, 25(1), 79-98.

Coetzee, P., \& Erasmus, L. J. (2017). What drives and measures public sector internal audit effectiveness? Dependent and independent variables. International Journal of Auditing, 21(3), 237-248.

Coetzee, P. \& Lubbe, D. (2013). Improving the efficiency and effectiveness of risk-based internal audit engagements. International Journal of Auditing, 18(2), 115-125.

Chambers, A. (1992). Effective internal audits, how to plan and implement. London: Pitman Publishing.

Cohen, A., \& Sayag, G. (2010). The effectiveness of internal auditing: an empirical examination of its determinants in Israeli organisations. Australian Accounting Review, 20(3), 296-307.
DeVellis, R. F. (2003). Scale development: Theory and applications (Vol. 26) (Second Edition). United States of America, California: Sage publications.

D’Onza, G., Selim, G. M., Melville, R., \& Allegrini, M. (2015). A Study on Internal Auditor Perceptions of the Function Ability to Add Value. International Journal of Auditing, 19(3), 182-194.

Drogalas, G., Karagiorgos T. \& Arampatzis K.(2015). Factors associated with Internal Audit Effectiveness: Evidence from Greece. Journal of Accounting and Taxation, 7(7), 113-122

Endaya, K. A. \& Hanefah, M. M. (2016). Internal auditor characteristics, internal audit effectiveness, and moderating effect of senior management. Journal of Economic and Administrative Sciences, 32(2), 160-176.

Erasmus, L., \& Coetzee, P. (2018). Drivers of stakeholders' view of internal audit effectiveness. Managerial Auditing Journal, 33(1), 90-114.

Felix, Jr, W. L., Gramling, A. A., \& Maletta, M. J. (2001). The contribution of internal audit as a determinant of external audit fees and factors influencing this contribution. Journal of Accounting Research, 39(3), 513-534.

Fowler Jr, F. J. (1995). Improving survey questions: Design and evaluation. California: Sage Publications.

Goodwin, J. (2004). A comparison of internal audit in the private and public sectors. Managerial Auditing Journal, 19(5), 640-50.

Gramling, A., Maletta, M., Schneider, A. \& Church, B. (2004). The Role of the Internal Audit Function in Corporate Governance: A Synthesis of the Extant Internal Auditing Literature and Directions for Future Research. Journal of Accounting Literature, 23, 194-244.

Hair J. F., Anderson R. E., Babin B. J. \& Black W. C. (2010). Multivariate data analysis: A Global Perspective (7th ed.), NJ: Pearson-Prentice Hall.

Institute of Internal Auditors (IIA) (2018). Internal Auditing's Role in Corporate Governance - Position Paper. Altamonte Springs, FL: The Institute of Internal Auditors.

Institute of Internal Auditors Research Foundation (IIARF) (2013), International Professional Practice Framework. Altamonte Springs, FL: IIA Research Foundation.

International Federation of Accountants (IFAC) (2013) Using the work of internal auditors and related conformity amendments. International Standard on Auditing (ISA) No. 610, New York, NY:The International Federation of Accountants.

Jensen, M. C., \& Meckling, W. H. (1976). Theory of the firm: Managerial behavior, agency costs and ownership structure. Journal of Financial Economics, 3(4), 305-360.

Lawshe, C. H. (1975). A quantitative approach to content validity. Personnel Psychology, 28, 563-575. 
Lenz, R. \& Hahn, U. (2015). A synthesis of empirical internal audit effectiveness literature pointing to new research opportunities. Managerial Auditing Journal, 30(1), 5-33.

Lenz, R., Sarens, G., \& D'Silva, K. (2014). Probing the discriminatory power of characteristics of internal audit functions: Sorting the wheat from the chaff. International Journal of Auditing, 18(2), 126-138.

Lenz, R., Sarens, G., \& Jeppesen, K. K. (2018). In search of a measure of effectiveness for internal audit functions: an institutional perspective. EDPACS, 58(2), 1-36.

Maletta, M.J. (1993). An examination of auditors' decisions to use internal auditors as assistants: the effect of inherent risk. Contemporary Accounting Research, 9(2), 508-525.

Mat Zain, M., Zaman, M., \& Mohamed, Z. (2015). The effect of internal audit function quality and internal audit contribution to external audit on audit fees. International Journal of Auditing, 19(3), 134-147.

Messier, W.F. and Schneider, A. (1988). A hierarchical approach to the external auditor's evaluation of the internal auditing function. Contemporary Accounting Research, 4(2), 337-353.

Mihret, D. G., James, K., \& Mula, J. M. (2010). Antecedents and organisational performance implications of internal audit effectiveness. Pacific Accounting Review, 22(3), 224-252.

Mihret, D.G. \&Yismaw, A.W. (2007). Internal audit effectiveness: an Ethiopian public sector case study. Managerial Auditing Journal, 22(5), 470-484.

Mustika, A. C. (2015). Factors affecting the internal audit effectiveness. Jurnal Akuntansi \& Auditing, 12(2), 89-109.

Onay, A. and Erdoğan, M. (2019). The Relationship Between Governance-Risk-Compliance (GRC) Approach and Internal Audit Function: Research of Structural Equation Model About The Effect of Internal Audit Responsibilities on GRC Approach. TIDE AcademIA Research, 1(2), 149-198.

Pallant, J. (2016). A Step by Step Guide to Data Analysis using IBM SPSS (6th Edition). USA: McGraw-Hill Education.

Prawitt, D. F. (2003). Managing the internal audit function. Florida:The Institute of Internal Auditors Research Foundation.

Salehi, T. (2016). Investigation factors affecting the effectiveness of internal auditors in the company: Case study Iran. Review of European Studies, 8(2), 224-235.

Sarens, G. (2009). Internal auditing research: where are we going? Editorial. International Journal of Auditing, 13(1), 1-7.

Sarens, G., Abdolmohammadi, M.J. \& Lenz, R. (2012). Factors associated with the internal audit function's role in corporate governance. Journal of Applied Accounting Research, 13(2), 191-204.
Sarens, G., \& De Beelde, I. (2006). The relationship between internal audit and senior management: A qualitative analysis of expectations. International Journal of Auditing, 10(3), 219-241.

Sawyer, L. B., Dittenhofer, M. A. \& Scheiner, J. H. (2005). Sawyer's Internal Auditing (5th Edition). Florida: The Institute of Internal Auditors.

Selim, G., \& McNamee, D. (1999). Risk management and internal auditing: what are the essential building blocks for a successful paradigm change? International Journal of Auditing, 3(2), 147-155.

Soh, D. S., \& Martinov-Bennie, N. (2011). The internal audit function: Perceptions of internal audit roles, effectiveness and evaluation. Managerial auditing journal, 26(7), 605622.

Spira, L.F. \& Page, M. (2003). Risk management: the reinvention of internal control and the changing role of internal audit. Accounting, Auditing \& Accountability Journal, 16(4), 640661.

Stevens, J. (1996). Applied Multivariate Statistics for the Social Sciences (5th Edition). Mahwah, NJ: Lawrance Erlbaum.

Stewart, J., \& Subramaniam, N. (2010). Internal audit independence and objectivity: emerging research opportunities. Managerial Auditing Journal, 25(4), 328-360.

Suwaidan, M. S. \& Qasım, A. (2010). External Auditors Reliance on Internal Auditors and Its Impact on Fees: An Empirical Investigation. Managerial Auditing Journal, 25(6), 509-525.

Tabachnick, B. G. \& Fidell, L. S. (2013). Using multivariate statistics (Vol. 6). Boston, MA: Pearson.

Van Peursem, K. (2005). Conversations with internal auditors: The power of ambiguity. Managerial Auditing Journal, 20(5), 489-512.

Vanasco, R.R. (1994). The IIA code of ethics: an international perspective. Managerial Auditing Journal, 9(1), 12-22.

Veneziano L. \& Hooper J. (1997). A method for quantifying content validity of health-related questionnaires. American Journal of Health Behavior, 21(1), 67-70.

Wood, D. A. (2004). Increasing Value through Internal and External Auditor Coordination. (Prepared for the IIA Research Foundation Esther R. Sawyer Scholarship Award) Florida: The IIA Research Foundation.

Yee, C.S.L., Sujan, A., James, K. \& Leung, J.K.S. (2008). Perceptions of Singaporean internal audit customers regarding the role and effectiveness of internal audit. Asian Journal of Business and Accounting, 1(2), 147-174. 